\title{
10
}

\section{The State That Cannot Absent Itself: New Caledonia as Opposed to Papua New Guinea and Australia}

\author{
John Burton and Claire Levacher
}

\section{Introduction}

The other contributors to this volume have come to broadly consistent views of the state in the two jurisdictions that are the focus of this book, Papua New Guinea (PNG) and Australia. The writers on PNG have profiled what community members aspire to: variously, a locally realised Utopia unhindered by the fact that 'the developers are foreigners and the State is only a concept' (Lihir: Bainton and Macintyre, Chapter 4); an end to 'waiting for the economic development' (Frieda: Skrzypek, Chapter 2); an Engan version of 'development, law and order, and prosperity', where the 'furious contest' for 'jobs, cash, houses, vehicles' can continue without restraint (Porgera: Golub, Chapter 3); and an end to the immorality of the 'corruption and neglect of an absent state' to save the world from entropic decline and, of course, bring the worldly rewards of development (PNG Liquefied Natural Gas (LNG) project: Main, Chapter 5). All the Indigenous voices represented capture a desire for something better than what national independence has so far brought them, but perhaps only the Frieda River people, in their feeling of simply being forgotten about (as opposed to the Huli feeling of being immorally neglected), expect the state to be the means of delivering it to them. The rest express a desire 
for their projects to trigger various versions of self-actualisation which, to judge from their various ways of expressing dissatisfaction, has yet to happen. Certainly, the overall picture is of an absent state. At Porgera, the executive part of the state, in the form of prime minister James Marape, suddenly woke up on 24 April 2020 to announce that Barrick Niugini Limited's lease renewal had been rejected. Was this a presence, or just feeble hand-waving? No one can be sure quite yet.

The writers on Australia portray a different, but similarly consistent picture of the Australian state. At the McArthur River Mine, the historic chicanery of the state and the company replicates the nineteenth-century dispossession of vast expanses of the Northern Territory for private gain (Lewis, Chapter 8). In the Northern Territory generally, poor 'recognition and regulatory guidance' means that the state is 'selectively absent' for Aboriginal people, has a 'fiscal absence' in the mining sector because of tax concessions and rebates to companies, and-as is notoriously the case in PNG-has a tendency to cut expenditure on Aboriginal communities to which mining benefits flow (Holcombe, Chapter 7). In Queensland's Western Downs region, the extremely rapid uptake of coal seam gas developments since 2010 highlights the state's 'organised irresponsibility' to approve resource developments without evaluating them effectively, leaving private land holders 'responsibilised' to do as best they can (Espig, Chapter 6). At the Century Mine, also in Queensland, the state is framed as taking 'action at a distance', with the ambitious Gulf Communities Agreement delivering unevenly distributed benefits to disadvantaged Aboriginal people whose land was needed for mining (Everingham et al., Chapter 9). All the above backs the decades-old finding that Indigenous economic status in remote parts of Australia is barely changed by the presence of long-life mines and with whose operators they have entered into seemingly favourable agreements (e.g. Taylor and Scambary 2005).

The consistency here is that, in all the areas described, local host communities' have an expectation that extractive industry projects will summon distant governments to be present to assist them with complex negotiations and afterwards to bring services which urban dwellers, in both jurisdictions, take for granted. Alas, this imagined emanation from nothingness disappoints time and again. In each case the kinds of state encountered, when stripped down to basics, cast themselves in the role of investor-enablers, and appear to be in retreat from (or never attained) the ideal of giving first priority to the human needs of citizens. The state is either remote or irrelevant (Skrzypek, Chapter 2; Bainton and 
Macintyre, Chapter 4), or it can be irresponsible, immoral or malevolent (Espig, Chapter 6; Main, Chapter 5; Lewis, Chapter 8). In other words, to a greater or lesser extent, local communities consistently view the state as looking after someone else's interests.

What if there was a different kind of state entirely?

This chapter responds to this question by comparing experiences of PNG and Australia with those of New Caledonia. The aims of this chapter are twofold. First, we use Jeffrey Wilson's model of different state forms to analyse resource nationalism across the three nation states and explore whether, when compared to PNG and Australia, New Caledonia is, indeed, a different kind of state. Second, we explore if and how the state is absent or present in resource contexts in these countries and ask whether the notion of 'absent presence' can be applied to the study of the state in resource settings in New Caledonia where, unlike in the cases from PNG and Australia, it would seem that in some ways at least the state cannot absent itself.

\section{Wilson's Kinds of States}

Wilson (2015: 399, 403-4) identifies three forms of resource nationalism that can be summarised as follows. A first form is associated with rentier states, where governments often fashion loyal societal coalitions, finance repressive apparatuses and engage in neopatrimonialism, exemplified by the Gulf states of the Middle East. A second form is associated with developmentalism, where governments maintain their standing through an 'ability to deliver industrialisation, economic modernisation and high rates of growth', exemplified by states in East Asia. And a third form is associated with liberal market economies, where the role of the state is (theoretically) limited to that of an arm's-length regulator, exemplified by the USA, Canada and Australia.

Of the three countries considered in this chapter, only Australia, having recently overtaken Qatar as the world biggest exporter of LNG (Owen 2020), could become a rentier state. However, as we discuss below, its resource rental regime is not capturing enough of the benefits to make this possible. PNG is not in the running, while New Caledonia has a mixed outlook but, here too, no one economic sector is poised for an East Asian-style boom (Bouard et al. 2016). All three places aspire to 
some kind of developmentalism, but none has achieved the desired goal of economic modernisation. Australia has de-industrialised in recent years and seems to have abandoned an industry policy. PNG is not doing at all well at translating resources incomes into development outcomes (UNDP 2014), and, again, New Caledonia has a mixed outlook, although no single economic sector is placed for rapid take-off. Elements of the last of Wilson's forms of the state, the liberal market economy, can be found in each but, as we will show, the hand of the state intervenes to varying degrees.

For our purposes, Wilson's model provides a useful way of conceptualising the question of state presence or absence in PNG and Australia, using New Caledonia as a point of comparison. To aid this objective, we have structured our analysis along three policy axes, based on three core sets of policies identified by Wilson in his modelling of resource nationalism. We have further clarified the three sets and define them as follows:

- Axis 1. Concerning ownership or equity. The key question here, regardless of who invests the initial capital, is who ends up owning resource projects and what political project this matches.

- Axis 2. Concerning the exercise of mining, oil and gas powers, other aspects of regulation, and non-regulatory influences on the conduct of the resource industries. The exercise of mining powers ranges from full state control of extractive resources (Bebbington 2014) to various degrees of delegation to authorities at the subnational level (Childs 2016). Whether regulation is or is not effective is likely to be a proxy for the presence or absence of the state at different levels.

- Axis 3. Concerning resource rents and benefit distribution. Thinking on this ranges from the position that states must attract investors on generous terms to the opposite idea that if foreigners want national resources they should pay as much for them as the market will bear. Once received, how should economic returns be shared out: should the state put them into its coffers, or how much should it share with other levels of government, local communities and landowners? Both dimensions of this problem raise difficult economic and political questions.

These three axes now provide the basis for comparison between PNG, Australia and New Caledonia. In the sections that follow, we draw upon these different dimensions or axes to consider how the state may be more or less present (or absent) in resource extraction contexts. 


\section{New Caledonia: A Different Kind of State}

New Caledonia became a French territory in 1853 and is now engaged in the process of decolonisation. A violent period in the 1980s known as 'the events' (Les Evénements), centred on Kanak ${ }^{1}$ struggles for independence, ended in a hostage siege on the island of Ouvéa. This triggered a first set of political agreements between loyalists and separatists, the Matignon-Oudinot Accords, negotiated in Paris in May and June 1988. The accords led to new initiatives for Kanak economic development and administrative decentralisation, seen as the first steps in a process of decolonisation. A territorial government was created; the previously wide powers of the High Commissioner, a delegate of Paris, were curbed; and provincial governments were set up for new North, South and Loyalty Islands Provinces. A second political agreement was signed in 1998, the Nouméa Accord, resulting in further transfers of powers from France, more formalised economic financing, and with provisions for up to three referendums on the question of independence from France. Two have now been held: the first, on 4 November 2018 , resulted in a 56.7 per cent 'no' vote while the second, on 4 October 2020 , resulted in a 52.3 per cent 'no' vote (HCRNC 2019, 2020). In 2020, the split between the Kanakdominated Islands and North Provinces, where 84.3 per cent and 78.3 per cent voted 'yes' respectively, and the loyalist-dominated South Province where 70.1 per cent voted 'no', was manifest. While the results are narrowing, the heavier population of the South Province, where voters cast over 100,000 votes in 2020 as against 53,000 in the other two provinces, means that the result in 2022's third referendum will be extremely tight.

The nature of government in New Caledonia is very distinctive and differentiates it from the other two countries explored here. In both Australia and PNG, governments are formed in winner-takes-all systems of government, but this is not the case in New Caledonia. Here government is formed in a tiered way, from a starting point of five-yearly general elections for 76 provincial seats in the assemblies of the South (40), North (22) and Loyalty Island (14) Provinces. Without further elections, a quota of the members of each assembly is selected by party list proportional representation to also sit in the Congress (South: 32 seats; North 15 seats; Loyalty Islands: 7 seats). The 54 members of the

1 Indigenous Melanesian inhabitants of New Caledonia. 
newly formed Congress then vote to determine the 11 members of the executive government of New Caledonia. From among their number, the 11 members of the government elect a president and vice-president. The government is termed a collegial government because it incorporates what in other jurisdictions would be opposition members. Its key role is to propose legislation for forwarding to the Congress for discussion and voting. An unwritten rule is that once the president is elected, the members of the losing bloc choose the vice-president.

A supra-governmental body, the Committee of the signatories of the Nouméa Accord (Comité des signataires de l'accord de Nouméa) meets annually in Paris to monitor progress on the implementation of the Nouméa Accord, nowadays bringing together an enlarged delegation of members of the Congress and mayors as well as surviving signatories from 1998. ${ }^{2}$ This is supported by the GTPS, the working group of the presidents and signatories of the Nouméa Accord (Groupe de travail des présidents et des signataires de l'accord de Nouméa) which meets locally. Technically there are further superior bodies, such as the Conseil d'Etat ('Council of State') to which appeals can be made, but these are part of the French state.

The implication for critical legislation, such as that concerning resource extraction, is that the make-up of the government has always reflected the spectrum of political positions held by the members of the three provincial assemblies and, in turn, among the electorate of New Caledonia. Critical legislation cannot therefore be changed easily by the biggest party to fit with its electoral platform, in disregard of the electoral platforms of its rivals. While a majority of the members of the government is all that is technically required to make a decision, in practice a broader consensus must be achieved because of the complexity of party positions in the Congress. If the minority were to be disregarded in the government, it would run the risk of chaos in the Congress and of joint positions collapsing in relation to other matters.

Because of the unusual manner in which its institutions of democracy are interlaced, it is possible to suggest that the state, in its territorial form in New Caledonia, cannot absent itself. The institutions were designed in the post-conflict situation in which France and New Caledonia were locked

2 The first meeting was held on 2 May 2000. The nineteenth meeting, chaired by the French prime minister, Edward Philippe, was held in Paris on 10 October 2019. 
together in May 1988 and have evolved over three decades into the form they have today. Whether it is due to the special design of the institutions, or that a kind of post-conflict vigilance on the part of all parties affects the way they operate, or that living people made the original agreements and they are still politically active, is not especially relevant to the present discussion. What is true is that the expression of the state in terms of policies, laws and governmental decrees must follow the political templates laid down in the foundational agreements-Matignon, Nouméa, Bercy, the Organic Law of 1999, etc. - and that deviations from them have not so far been possible.

This does not mean that there are no conflicts among lower-level entities; indeed, there have been bitter ones concerning which shareholder group should control this or that enterprise and which financing entity should or should not exercise influence or should yield its capital to local interests. But it does show the difference that the structures of the state can make to its relative absence or presence in resource extraction contexts. The value of this point of comparison is that it helps to highlight some of the structural similarities between PNG and Australia where they might otherwise be rendered invisible or masked by other more seemingly obvious differences, such as state capacity to use mineral wealth for the benefit of the population, as we discuss below.

\section{A Short History of Mining in New Caledonia}

New Caledonia's mineral wealth is linked to its nickel mining industry. Nickel was discovered there early in the colonial period, with exports starting in 1874 . Today mining is carried out, in the first place, by three large companies that operate their own refineries. The first is Société Le Nickel (SLN), founded in 1880, from time to time partly state-owned, and now majority-owned by the French multinational group Eramet (see Newbury 1955; Bencivengo 2014; Black 2014). SLN's Doniambo nickel refinery on the outskirts of Nouméa has operated since 1910. The second is Koniambo Nickel SAS (KNS), a joint venture between the Société Minière du Pacifique Sud (SMSP) and Glencore plc. KNS has built a refinery in the North Province. The third is Vale NouvelleCalédonie SAS (Vale NC), a subsidiary of the Brazilian energy and mining group Vale SA. It has built a refinery at Goro in the South Province. 
Twenty or more second-line companies that are only engaged in parts of the process of mining, and do not do their own refining, operate across the territory and are loosely known as 'petits mineurs' (or 'small miners'). The fact that some of these 'small miners' are well capitalised, hold large concessions and directly export nickel (Bouard et al. 2019), only seems to reinforce Sarah Holcombe's observation (Chapter 7, this volume) that there is very limited consensus around the definition of a 'junior miner'.

The French state has asserted a presence in mining in various ways from 1859 when French mining law was first extended to New Caledonia. However, the hand of the state in mining was weakly felt to start with and a local decree in 1873 authorised mining on pegged claims ('possession par invention'), similar to what is seen in Anglophone countries (Le Meur and Mennesson 2011). The state remained a spectator while the Parisbased bank Rothschild Frères owned the main producer SLN from 1883, and after its merger in 1931 with its main rival, André Ballande, during the Great Depression. When the Second World War started, trade with Germany and Japan, which made up 95 per cent of exports before the war, came to a stop, halting the economy until the US entered the war and took all of New Caledonia's nickel production.

In the 1960s, in promoting the autonomy of the territory, the Union Calédonienne, ${ }^{3}$ expressed interest in attracting foreign capital. But when the global price of nickel boomed in 1967, the French Secretary of State, Pierre Billotte, declared to the National Assembly in Paris that 'there can be no question of delivering New Caledonian nickel to a foreign trust' (Brou 1982: 112). Whereas previously licencing had been handled at the territorial level, the 1969 'Billotte Laws' classified nickel, chromium and cobalt as strategic raw materials and transferred control of them to the Ministry for Industry. This period also saw French interest in creating a company with French investment majority to face off foreign investors, but nothing eventuated before a slump in prices in 1972 threatened the entire industry with collapse. To prevent this from happening, a 50 per cent stake in SLN was taken out in 1974 by the (then) state-owned oil company, Elf Aquitaine. Further restructuring took place in 1985 when another majority state-owned enterprise, Eramet, boosted state-ownership to 85 per cent of SLN. Since this peak of state control, metropolitan

3 A political party founded in 1953 with the goal of promoting more autonomy for New Caledonia, the Union Calédonienne moved from its original multi-ethnic base to become part of the pro-Independence FLNKS in the 1970s. 
public ownership of Eramet has been progressively diluted, then finally reduced to zero by offloading the last third to a New Caledonian entity STCPI (see below) in 2000.

\section{Modernisation of the Mining Sector}

Up to this point, in our exploration of the role of the state in resource contexts in New Caledonia, the state we are concerned with was exclusively conceived of as that of metropolitan France. After 1988, though, the political solutions of the metropolitan state pursued a new set of objectives directed at (a) averting violence and (b) redressing the injustice of the underdevelopment of Kanak communities, particularly through the doctrine of economic rebalancing (rééquilibrage). These objectives can be seen as aspiring to non-traditional, more progressive 'state effects' and creating new institutions able to define and enforce collectively binding decisions on members of society (Lund 2006: 685).

Mining had not been mentioned in the 1988 Matignon Accords, but it soon became integrated into pro-independence claims for sovereignty as a precondition for talks ${ }^{4}$ in the following years. Simultaneously, the presence of the French state in the New Caledonian mining industry mutated from direct involvement-it was selling off most of the concessions it held globally at the time ${ }^{5}$ - to indirect involvement, seen in its capital injection into the newly formed mining and metallurgical company, Société de financement et d'investissement de la province Nord (SOFINOR), a financing entity for the new Kanak-run North Province. The leader of the anti-independence groups in New Caledonia, Jacques Lafleur, was both a signatory to the accords and a major player in the nickel industry, through his ownership of another extractive company, Société minière du Sud Pacifique (SMSP). In a surprise move, Lafleur sold his shares to SOFINOR on 5 October 1990, giving it an 85 per cent holding. SMSP focused on the export of nickel ore for the next eight years.

4 The catchphrase préalable minier ('mining precondition') expressed the specific political position that talks could not proceed if mining issues were not included at the outset.

5 Between 1990 and 1995, the Bureau de Recherche géologique et minière divested much of its global mining portfolio; in New Caledonia its concessions were mostly acquired by SLN and Inco (Pitoiset and Wéry 2008: 101). 
The first strictly mining-related agreement was the Bercy Accord, signed on 1 February $1998 .{ }^{6}$ Two months later, a joint venture was entered into between SMSP (51 per cent) and Falconbridge of Canada (49 per cent) to form Koniambo Nickel SAS (KNS), which began to plan a USD5.3 billion nickel processing plant at Vavouto. The project was incentivised, along with the Goro project in the South Province, with a tax holiday for 15 years in 2001, with further exemptions granted in 2004. Construction started in 2007 after Falconbridge was bought by Xstrata, and the plant entered production in 2013 as Xstrata was bought by Glencore plc. This was a new form of state intervention-via the politics of providing a financing vehicle for a subterritorial provincial government - which has resulted in the North Province having majority control of both the Koniambo massif and its linked processing plant.

The Koniambo project was conceived from the start as an economic engine around which the North Province as a whole might develop. Far from the state being absent-malevolent, as seen in Australia, and absent-irrelevant, as seen in PNG, the Koniambo project is the projection of the presence of two levels of the state in an industry: foremost as part of a long-term political project of the Kanak-run North Province and its mining company, SMSP; and financing mechanisms ultimately devised by the French state in the shadows behind SOFINOR.

The North Province and its mining arm SMSP have been able to expand into offshore processing of ore unsuitable for processing at Koniambo (Bouard et al. 2016: 121-2):

- Investing in a new processing plant in Gwangyang, South Korea, in 2006, creating a Caledonian offshore company, the SSNC (Société du Nickel de Nouvelle-Calédonie et de Corée).

- Forming the New Caledonia-based Nickel Mining Company (NMC) with 51 per cent ownership by SMSP and 49 per cent by the Korean steelmaker POSCO, to feed the Gwangyang plant from NMC concessions at Oauco, Poya, Nakéty and Kouauoa.

- Concluding an agreement for a nickel processing plant in Guanxi Province, China, to also have 51 per cent ownership by SMSP (Jinchuan project) and for the offshore processing of New Caledonian ore.

6 Signed by SMSP, Eramet and its subsidiary SLN, and three French ministries (Economy and Finance, Industry, Overseas Territories), in the presence of the French Agency for Development (CFD, now AFD). 
At the same time, the Goro project, located in the communes of MontDore and Yaté, came into being outside the template involving Kanak interests that the Matignon and subsequent agreements provided for. It began with the acquisition of mining titles at Goro by Inco of Canada in 1992. Inco tested a pilot plant in 1999 and began construction of a refinery in 2002. Technical problems resulted in the suspension of construction until 2005. Inco was acquired by Vale of Brazil to form Vale NouvelleCalédonie (Vale NC), but projected costs rose from USD1.4 billion to an eventual USD4.3 billion when it began operating four years after the Vale takeover, in 2010. The project has most recently been described as having cost USD9 billion (Mainguet 2019). Ownership was transferred to Prony Resources, a 51 per cent locally owned consortium, in March 2021.

Goro faced stiff opposition from both local communities and civil society organisations between 2001 and 2008. Loyalist forces dominate in the South, and the manner of developing the project was seen as a way to assert the old way of doing things. Three chieftaincies in Yaté formed the Rhéébu Nùù ('Eye of the Country') committee, which was successful in widening the circle of stakeholders to include local interest groups (see Demmer 2007; Horowitz 2009; Levacher 2016, 2017). This led to the signing of a Pact for the Sustainable Development of the Far South (Pacte pour un Développement Durable du Grand Sud) by Vale and local stakeholders, including Rhéébu Nùù, in 2008 (Le Meur, Horowitz and Mennesson 2013; Horowitz 2015).

\section{Three Axes of Resource Policy: Comparisons with PNG and Australia}

So far in this chapter we have introduced Wilson's model of resource nationalism and provided information necessary to establish New Caledonia as a point of comparison with PNG and Australia. For the remainder of this chapter, we turn our attention to the three policy axes, based on core sets of policies identified by Wilson, along which we make comparisons between the three countries. The axes are drawn along the critical issues of ownership or equity; exercise of mining powers, other aspects of regulation and non-regulatory influences; and resource rents and benefits distribution, respectively. We use them here to consider ways in which the state is absent and/or present in resource extraction contexts in PNG, Australia and New Caledonia across the identified policy areas. 


\section{Axis 1: Concerning Ownership or Equity}

\section{Papua New Guinea}

The PNG government has frequently expressed an intention to own equity in resource projects. At the Ok Tedi copper and gold mine in the Western Province, the state started as a 20 per cent owner when the mine opened in 1984 . Wounded by the environmental record of the mine, the majority owner BHP placed its 52 per cent share ownership in an offshore company structure, the PNG Sustainable Development Program (SDP), in 2001, and left the country. In the 2000s, SDP's and the state's shares grew to about 65 per cent and 35 per cent respectively as minor partners divested, but a long-standing feud between the 2011-19 prime minister, Peter O'Neill, and the 1999-2001 prime minister, Mekere Morauta, changed things when Morauta became chairman of SDP. O'Neill, who hails from Southern Highlands Province, pushed through legislation to cancel SDP's shares, nationalise the mine and replace Morauta as chairman, saying, 'I ask, who is he? He's not from Western Province. He has done enough damage to this country and he has protected his foreign friends enough'. He added, 'the people of Western Province must run the company' (Nalu 2013). But when the new executive team was announced, it did not noticeably include anyone from Western Province, and O'Neill appointed a prominent Australian as the CEO.

At Porgera the state initially took a 10 per cent stake in the mine, which opened in 1990. When the mine produced a million ounces of gold each year, the government of Paias Wingti demanded a greater stake (Davis 1993; Jackson and Banks 2002: 191-8). Seemingly a textbook example of a state wanting to take a lead role in managing national mineral wealth, the next five prime ministers gradually lost interest, and the government's shareholding in Porgera was diluted from a high of 25 per cent in the mid-1990s to 0 per cent in 2007. Most of the shares ended up back in the hands of the operator to 2020, the Porgera Joint Venture, 95 per cent owned by Barrick Gold and Zijin Mining. In 2020, James Marape's government refused an application for a 20 -year mine lease extension, under the policy slogan 'Take Back PNG' (see Afterword, this volume). Marape prepared poorly for the announcement, with no obvious plan as to what new entity would run the mine. Meanwhile, 2,700 workers were laid off just as the gold price passed USD2,000/oz, a record high. 
In the oil and gas sector, the O'Neill government borrowed AUD1.2 billion from the Union Bank of Switzerland (UBS) to buy a 10 per cent stake in Oil Search, a partner in the PNG LNG project, on the advice of consultants. Commentators deprecated the move (Yala et al. 2014), and an official report concluded that O'Neill and several others had broken the law (GPNG 2018). When the oil price slumped in 2016, PNG abandoned the loans at a loss of about a third of the amount borrowed (Grigg et al. 2019). Kumul Petroleum Holdings, the state-owned oil and gas company, and the beneficiary of the loans, made losses of PGK481 million in 2016 and PGK1.8 billion in 2017, despite being a 16.6 per cent partner in the PNG LNG project which has been exporting gas since 2014.

\section{Australia}

Taking a different approach, Australia does not seek government equity in the extractive industries. A short-lived Petroleum and Minerals Authority was created in 1974 but was struck down by the High Court over states' rights (Bambridge 1979). However, Australia invests in other ways. It has recently taken up a long-standing commitment to the International Energy Agency to maintain a 90-day oil reserve (Taylor 2020), and its 'critical minerals strategy' incentivises various kinds of research funding allocations to universities and the CSIRO (the Commonwealth Scientific and Industrial Research Organisation) (AFG 2019, 2020). The Northern Australia Infrastructure Facility offers concessional loans to resource companies to upgrade ports, airports, and road and rail links, while many states own or part-own energy retailers like Energy Queensland (Queensland), Aurora Energy (Tasmania) and Horizon Power (Western Australia).

A further 'other way' concerns the Australia-Timor Leste sovereignty dispute. In 2004, Australian secret agents bugged Timor Leste's delegation during talks over oil and gas sharing in the Timor Sea leading up to the signing of a treaty providing for 50 per cent of the income to be allocated to each country. When the spying operation was exposed, Timor sued Australia in the Hague and negotiated a new agreement giving 80 per cent of the income to Timor Leste and 20 per cent to Australia. Agreement on the maritime boundary between the two countries, and therefore the absolute ownership of the oil and gas, was settled in 2018 (Rothwell 2018). 


\section{New Caledonia}

We have already discussed the long-standing political project for New Caledonia to assume majority ownership of resource projects. In the South, both Indigenous and environmental movements favoured the South Province investing in the Goro Nickel project as the North Province had done at Koniambo. The idea was endorsed politically at a meeting of the Comité des signataires and in 2005 a new entity, the SPMSC (Société de participation minière du Sud calédonien), acquired a stake in Goro Nickel, though a small one. In 2000 the three provincial governments created yet another equity vehicle, STCPI (Société territoriale calédonienne de participation industrielle), as a step towards joint involvement in mining. By means of various transfers from the French state, via each province's financing arms-SOFINOR, PROMOSUD, SODIL, ${ }^{7}$ etc.—STCPI had acquired 34 per cent of the historically largest nickel company SLN by 2007. As shown in Figure 10.1, all three onshore refineries are part-owned by provincial governments, with the North Province's 51 per cent of Koniambo being the highest. The same and/or linked entities, like Nord Avenir in the North Province, also offer financing for mining contractors.
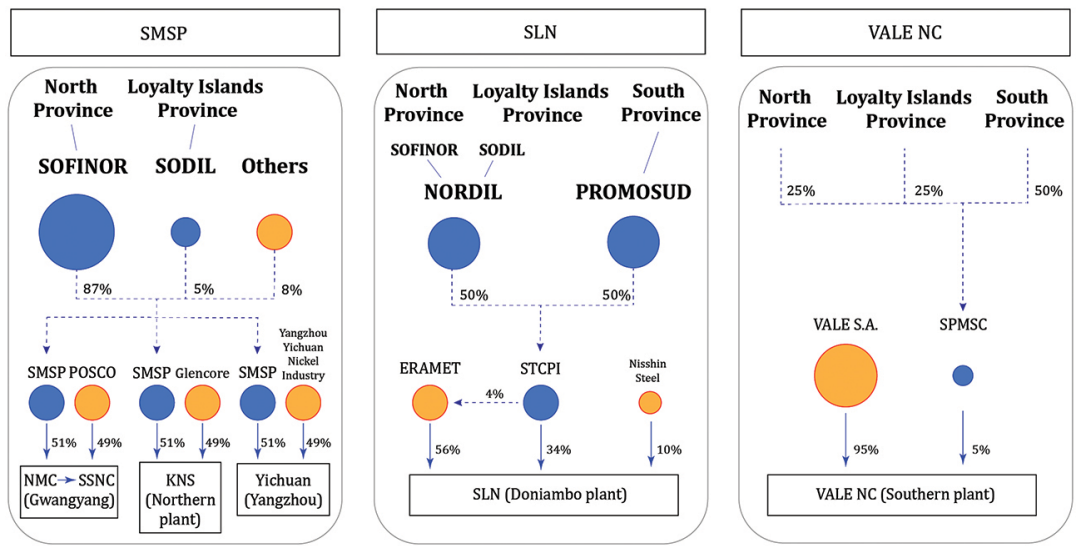

Figure 10.1 Provincial shareholding in New Caledonian nickel refineries Source: C. Levacher (data to 2020)

7 PROMOSUD, Société De Financement et de Développement de la Province Sud; SODIL, Société de Développement et d'Investissement des Îles. 


\section{Axis 2: Concerning the Exercise of Mining, Oil and Gas Powers, Other Aspects of Regulation, and Non-Regulatory Influences on the Conduct of the Resource Industries}

\section{Papua New Guinea}

The first piece of mining legislation to be passed after PNG's independence in 1975 was the Mining (Ok Tedi Agreement) Act 1976 (Jackson 1982; Burton and Haihuie 2017: 22-5). A working group drawn from the major economic ministries in Port Moresby was the point of consultation for key decisions. Reference to local viewpoints and interests was almost non-existent (Burton 1997). Ok Tedi is well known for the environmental damage done to the Ok Tedi and Fly Rivers below the mine, and landowners in the impact area, in alliance with international lawyers, mounted litigation so damaging that it eventually forced BHP out of PNG, as recounted above (Banks and Ballard 1997; Kirsch 2001, 2007). All later extractive industry projects have been governed by national mining and environmental legislation: currently, the Mining Act 1992, the Oil and Gas Act 1998, and the Environment Act 2000 (Filer and Imbun 2009). However, each project to date has been characterised by localised agreements (Burton and Haihuie 2017) emerging from Development Forums (Filer 2008) where the state takes second place to negotiations between companies and landowner representatives (Bainton 2010; Main, Chapter 5, this volume).

In reality, the state is barely visible in regulatory matters. Just to cite waste disposal problems, the government has watched on while landowners have rebelled, sued, lobbied ministers, engaged with international NGOs, or got their (opposition) MPs to complain about damage to five separate river systems: Jaba River (Bougainville mine: May and Spriggs 1990), Ok Tedi-Fly river system (Ok Tedi mine: Banks and Ballard 1997), PorgeraLagaip river system (Porgera mine: CSIRO 1996; Bainton et al. 2020), Angabanga River (Tolukuma mine: OCAA 2004), and Watut River (Hidden Valley mine: Ketan and Geita 2011).

From the 1990s, international mining companies operating in PNG have turned to sustainability reporting to assure investors about their social and environmental performance. Close examination, though, reveals a patchy approach to applying standard reporting criteria (Burton and Onguglo 2017) and selective amnesia over past failings that poor government 
alertness allows operators to get away with. A quarter of a century later, mining, oil and gas policy is out of step with several cycles of national development plans (e.g. GPNG 2009, 2015) and has a puzzling fit with PNG's international commitments to initiatives like the Sustainable Development Goals and the Paris Agreement. Worst, the Department of Petroleum Energy is unfit for purpose: its ministers have failed to take up external offers of help and the department has not published an annual report since 2009 (PNGEITI 2019).

\section{Australia}

Unlike PNG, in Australia responsibility for the regulation of the extractive industries is located at the subnational level in state and territory governments and governed by subnational legislation. This means that the expectations placed upon extractive companies differs between states and territories. For example, as Holcombe has observed, there is a large gulf between the requirements and guidance for environmental and social impact assessment for new extractive projects in New South Wales compared with the Northern Territory. As a result, we also find a good deal of variation in the capacity and willingness of state and territory governments to closely regulate the activities of extractive companies to minimise social and ecological impacts, and to harness the economic benefits of extraction to provide broad-based development for local project-affected communities and the wider population. This partly helps to explain the incomplete or uneven nature of the state, where different actors experience different incarnations of the state in stronger or weaker ways, or as a more or less consequential force supporting some interests and not others. These subnational differences are particularly apparent when it comes to unconventional gas extraction and development, which is sometimes known as 'fracking'. While some states have placed a moratorium on unconventional gas extraction, others have actively encouraged these developments. But the discrepancy between the state's sovereign power to approve extractive projects and its ability to oversee and responsibly regulate the sector can be problematic, particularly for local residents who are caught up in this disparity (Espig, Chapter 6, this volume).

The influence of the coal seam gas industry, and the feeble regulatory capacity of the Queensland Government, point to larger considerations around the degree of state capture by industry and a 'growth-first' political economy in Australia. The considerable political influence and lobbying 
power of the extractive industries has found a favourable reception among successive federal, state and territory-level governments-especially in Queensland, Northern Territory and Western Australia. Nowhere is this more evident than in regards to Indigenous interests. Since at least the 1970s, the mining and petroleum industries have become increasingly influential in Australian politics and policy making. As Jon Altman has previously noted, historically the mining industry's relationship with the state in terms of land rights and native title has been fundamentally oppositional, seeing consent or negotiation provisions where the state has supported land rights as just another regulatory hurdle in the way of unimpeded access to Aboriginal land for mineral exploitation (Altman 2009: 25). In the 1970s, the Australian Mining Industry Council, now known as the Minerals Council of Australia, strongly opposed land rights, and mounted an effective campaign against these rights in Western Australia. These diminished rights are now reflected in Western Australia's Aboriginal Heritage Act 1972, specifically Section 18 which provides a legal basis for extractive companies to destroy specified Aboriginal heritage objects and places. This piece of legislation has served the interests of the extractive industries over Aboriginal people, most recently witnessed in the apparently legal destruction of the Juukan Gorge by Rio Tinto in 2020 (see Afterword, this volume). So while many multinational extractive companies working in Australia have embraced the rhetoric of corporate social responsibility-including Rio Tinto, who was once at the forefront of this corporate shift (Kemp and Owen 2018)—it would seem that in practice these higher corporate standards are trumped by lower legislative standards.

\section{New Caledonia}

A key institutional effect of the 1998 Bercy Accord was the transfer of mining powers from Paris to New Caledonia. An organic law ${ }^{8}$ followed that prescribed work on a Framework for the Development of Mineral Resources (Schéma de Mise en Valeur des Richesses Minières) and decreed that future decisions relating to mining must follow the principles set out in it. It was meant to be ready by 2004, when a local Mining and Energy Department was indeed created-DIMENC, the Direction de l'Industrie, des Mines et de l'Energie de la Nouvelle-Calédonie-but rounds 
of consultations across New Caledonia took five more years until the Framework, and a territorial mining law, were adopted concurrently by the Congress of New Caledonia.

The Framework and the mining law not only set out the rules by which the mining should be run, as standard mining policy and legislation might be expected to do but, backed by the organic law, they also act as almost inviolable constitutional documents of a longer-term view of the mining industry in New Caledonia. That is why the adoption in 2015 of a 'nickel doctrine' by the territory-wide pro-independence coalition FLNKS (Front de Libération Nationale Kanak et Socialiste) raised strong opposition especially from the smaller producers and 'truckers' (rouleurs) who wanted to retain the freedom to export raw nickel to lower-cost overseas processors (Demmer et al. 2018). This policy advocates: better use of nickel resources by seeking efficiency gains in local mining operations and by striking economic agreements more advantageous to local interests; ceasing exports of unprocessed nickel ore (except those destined for New Caledonian offshore processing plants); and promoting the territorially owned STCPI to reach a 51 per cent shareholding in SLN (Bouard et al. 2016: 122) up from 34 per cent at present (Figure 10.1). The question of unprocessed mineral exports and the balance prescribed by the Framework between exporting nickel and doing onshore processing continues to lie at the heart of political contestation over the nickel industry (Demmer 2017; Anon. 2020b).

The combination of the political agreements (Matignon-Oudinot and Nouméa), the increased importance of mining issues in politics since the 1990s and the rise of environmental concerns has led to an evolution in the relations between mining companies and local populations. Newer negotiated agreements aim to recognise the special Kanak link to the land and to compensate for the impacts of mining in a variety of ways, notably in undertakings regarding employment and contracting by local entities.

Another point of evolution in regulations in the last two decades is the rise in awareness of New Caledonia's status as a biodiversity hotspot and increasing local concerns over environmental impacts combined with calls for environmental compensation (Levacher and Le Meur 2019). This is illustrated in the fact that protests around the Goro Nickel mining project in the south played a key role in the inscription of the New Caledonian lagoon as a UNESCO World Heritage Site in 2008 (Merlin 2014; Horowitz 2016). At the institutional level, both North and South Provinces introduced new environmental legislation in 2008-09, which 
include compulsory environmental impact assessments, with a special emphasis on impacts on ecosystems with heritage value and protected species, provisions for compensation, action plans for mitigating impacts, and long-term monitoring and reporting of results.

\section{Axis 3: Concerning Resource Rents and Benefit Distribution}

\section{Papua New Guinea}

Despite a perpetually renewed national rhetoric of reaping benefits from the exploitation of the country's endowment of natural resources, the latest version of which is James Marape's mantra of 'Take Back PNG', the effectiveness of the state in collecting fair returns has waned over time. The Australian colonial administration included tax incentives in its 1967 agreement with the mining company Conzinc Riotinto of Australia (CRA) to develop the Bougainville copper mine. A normal tax regime prevailed by the time of independence and an additional profits tax (Garnaut and Clunies Ross 1975) was brought into use, exemplifying Wilson's third policy axis: the use of tax mechanisms to capture economic rents for public purposes. This was when the state's powers to control income from mining were strongest. In the last year of full operations, the government's share amounted to 66 per cent of revenues from the Bougainville mine, after operating costs, while CRA's shareholders received 34 per cent (Bougainville Copper Limited 1988: 3-4).

As in New Caledonia, it was assumed that people in Bougainville would benefit from business and employment; compensation payments to traditional landowners were small. Local grievances escalated during the 1980s (Filer and Le Meur 2017: 18-9) until landowners demanded PGK10 billion (approximately USD11.6 billion) in compensation and 50 per cent of future profits to be shared by local stakeholders (AGA 1989). As is well known, rebel landowners fought a decade-long civil war against the PNG Defence Force (Filer 1990; May and Spriggs 1990; Braithwaite at al. 2010). A referendum on independence from PNG was held in 2019 at which over 98 per cent of the electorate voted 'yes'.

Not surprisingly, later mining agreements made greater provisions for benefits to be made to local communities (Filer 1997). Royalty had been set at 1.25 per cent of production at Bougainville and Ok Tedi, of which the host province and landowners took 95 per cent and 5 per cent shares respectively. In 1989, landowners at Porgera negotiated 
a balance of 77 per cent (province) and 23 per cent (landowners and local institutions). In 1995, the Lihir landowners negotiated a balance of 50 per cent (province), 50 per cent (landowners and local institutions) and an increase in the rate of royalty to 2 per cent of production (Bainton 2010: 168). In turn, this caused the Porgera landowners to renegotiate their agreement, and from mid-1995, they too shared royalty at the rate of 2 per cent and the breakdown became 50 per cent (province) and 50 per cent (landowners and local institutions) (Banks 2001: 44).

On the side of compensation and business development grants, where in the 1970s landowners reckoned in the tens of thousands of PNG Kina, in the 1980s they began reckoning in hundreds of thousands of Kina (e.g. Banks 2001), in the 1990s in millions of Kina (e.g. Bainton 2010: Table 5-1; Golub 2014), in the 2000s in tens of millions of Kina (e.g. Johnson 2012) and in the 2010s in hundreds of millions of Kina (Nicholas 2011, 2019).

All this points to the state exhibiting a weaker and weaker capacity to control resource revenues: (a) its local presence, manifesting in its bargaining power with citizens, has faded and (b) its ability to collect mining and petroleum taxes from corporations has faltered. Tax receipts averaged AUD650 million/year 2010-12, but only AUD85 million/year 2014-17 (Figure 10.2).

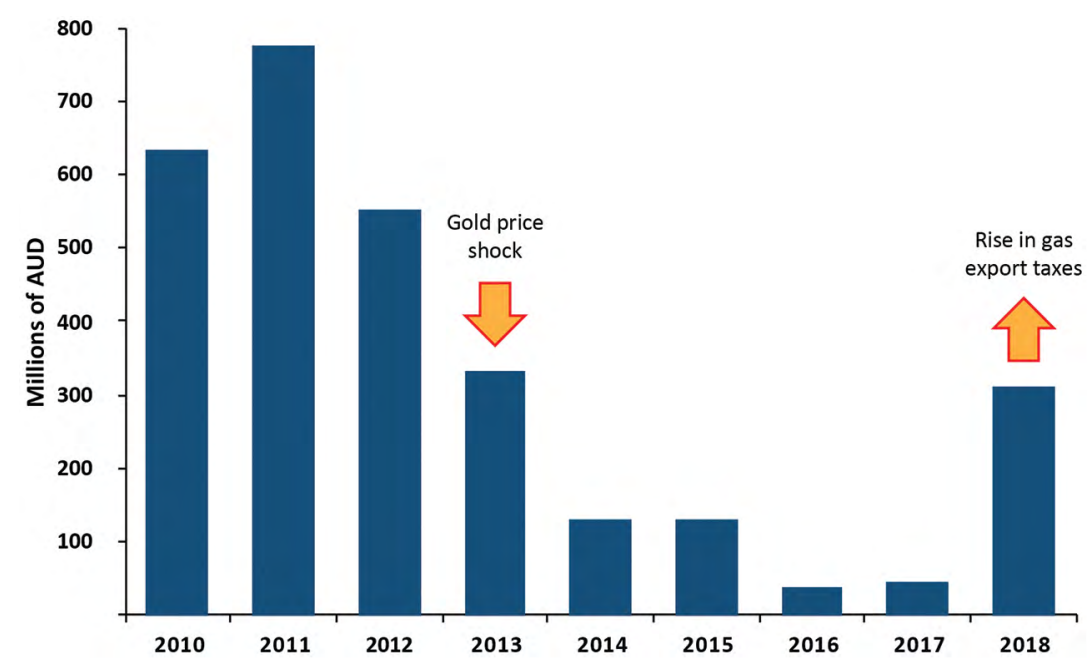

Figure 10.2 Mining and petroleum taxes collected in PNG during the 2010s

Source: PNG Department of Treasury data 2010-18 
A brief gold price shock in mid-2013 was a local trigger for gold miners to restructure their tax affairs, but this was merely an acceleration of worldwide trend for multinationals to more aggressively minimise tax. It should be noted that Australia (below) has its own troubles with resource rents, but as a developing country PNG has fewer means of redress and PNG's long-awaited sovereign wealth fund, intended to capture LNG revenues and stabilise the economy (Osborne 2014) and supposed to start accumulating from 2014, has still received no deposits (Anon. 2020a). As Banks and Namorong (2018) note, something has gone significantly wrong with PNG's investment settings.

\section{Australia}

Extractives-friendly politicians in Australia constantly boast about the number of jobs created in the key producing states, with a multiplier effect generating benefit in the wider economy. However, the tax take from resources is acknowledged as inefficient.

The 2010 'Henry Tax Review' (AFG 2010) recommended that the government should replace the existing regime of state-based mining and petroleum royalties with a resource rent tax. As is well known, the attempt by the then Labor Government to introduce a Resource Super Profits Tax (RSPT) — matching the existing petroleum resource rent tax (PRRT) was met with strident industry protests: the announcement was 'shocking' (Rio Tinto), 'highly regrettable' (Xstrata) and 'a surprise attack on us' (Fortescue Metals). The Minerals Council of Australia (MCA) - the peak lobby group representing the mining industry—ran an advertising blitz over the next two months, a key factor in the Labor Party replacing its leader, Kevin Rudd, in mid-2010 (Davis 2011). His successor, Julia Gillard, introduced a weaker Minerals Resource Rent Tax (MRRT) which was initially forecast to raise AUD3.7 billion a year, but net revenue was only AUD88 million in its two years of operation, 2012-14. Reasons for its failure have been split among weak commodity prices, 'industry capture' of the process of designing the legislation-BHP, Rio Tinto and Xstrata had a hand in this-and insufficient technical expertise in the Treasury (Valle de Souza et al. 2016). The situation is no better in the energy sector, where it could be decades before the PRRT brings significant returns from new gas projects coming online in the north of Australia (AFG 2016: 4). 
The MCA says its members 'dig deep' to pay royalties and tax, contributing AUD39.2 billion to public finances in 2018-19 (DAE 2020; Zakharia 2020). But data from the Australian Taxation Office (ATO) shows that many of the largest extractive companies, with collective revenues of AUD54.5 billion, paid no tax at all in 2017-18, including Chevron, ExxonMobil, Woodside, Shell, Santos, Peabody Coal, Yancoal and BHP. ${ }^{9}$ In recent years, the ATO has taken to the courts to recover unpaid tax. In 2018, Chevron settled a dispute for AUD866 million concerning loans between subsidiaries in different countries. BHP, which reduced tax by using the 'Singapore Sling', a method of transfer pricing via Singapore, settled claims for AUD529 million in 2018 (Chenoweth 2020). Rio Tinto, which does pay tax, faces action over AUD500 million in the transfer pricing of aluminium and iron ore (TP News 2020).

\section{New Caledonia}

The preferred method of obtaining returns from the mining industry in New Caledonia is through dividends arising from provincial equity-holding in mining companies, rather than from production levies or royalties, and by adding as much economic value as possible by maximising onshore processing. In the current absence of a royalty regime, benefits to local communities arise largely as government spending on infrastructure and services, and through opportunities for employment and subcontracting, especially when agreements were signed. However, it seems inevitable that some form of production levy or royalty ${ }^{10}$ will be introduced eventually; both a recent agreement at Kouaoua (Mainguet 2020) and the proposals currently before the Congress to permit mineral exports are believed to contain provisions for a levy as a form of compensation (Lalande 2020).

\section{Discussion}

Wilson's three policy axes provide an informative way to see the presence or absence of the state. It is suggested that two particular phenomena are shared between the three country contexts explored here.

9 See: data.gov.au/data/dataset/corporate-transparency

10 The French term redevance is frequently heard in demands by local communities. While redevance is the standard translation of 'royalty', the French term has additional meanings that royalty does not in English. 
First, each version of the state has problems collecting resource rental incomes. PNG appears addicted to attracting new projects to repair the budget problems caused by the old ones, only to again fall into the trap of offering overly generous tax holidays and other incentives. Australia has a huge resource industry, but it is not doing a lot better at getting good returns on exporting the national wealth. New Caledonia is at the mercy of the fluctuating price of a single commodity and, as a high-cost producer, struggles to match its political commitments to onshore processing with the reality of lower-cost competition in China, South Korea and elsewhere. Sometimes, different dimensions of the same state present a very different face to different parts of the same issue. For example, political leaders can see themselves as enablers of the extractive industries, while tax collectors like Australia's ATO are locked in combat against large corporationsan observation which points to the multivalence of the state.

Second, if the domain of the feasible lies in the hands of transnational corporations, putatively regulated by each state in its own way, it is increasingly the case that their activities are moderated by local actors with their own points of view and which none of the states (or corporations) has found a way to consult with in an optimal way. We see numerous disputes with landowners in PNG; blockades and vandalism in New Caledonia, where the label 'conflit des coutumiers' (approximately: 'conflict with clans in the local communes') conceals much complexity; and polarising political stand-offs in Australia forming part of the so-called 'Culture Wars' (Wallace 2019) between conservative and progressive political actors.

Issues of this type have been widely discussed elsewhere in terms of 'glocalisation'-the simultaneous movement of influence away from states, 'upward' to globalised international capital and 'downward' to local citizens' groups (Swyngedouw 2004; Le Meur, Ballard, Banks and Sourisseau 2013). While the processes of glocalisation are evident in all three places, it is only in PNG and Australia that they are accompanied by a series of 'cut-offs' of the democratic will of voters. The two countries have electoral systems where citizens elect representatives to parliaments, but where the range of viewpoints canvassed in elections is greatly simplified by the process of forming governments. Only the viewpoints of the winning parties prevail; those of the opposition parties, and the electors who voted for them, fail a first cut-off and are discarded. The process of forming a cabinet of ministers from the members of the winning parties further forms a second cut-off. Only ministers and their assistants, 
a small handful of winning party representatives in a parliament, translate the policies of their parties into the actions of government. In this way, governments can adopt courses of action that citizens did not broadly vote for and that ultimately distance them from their electorate and election promises - though governments have long sought to persuade citizens after the fact that particular policies are what they wanted all along. The absence of politically alternative voices in the executive can mean that decision makers are susceptible to industry capture; if so, 'successful' legislation may be that which is smiled on by interests outside mainstream politics, not by a consensus of the parliament.

\section{Conclusions: What a Difference the State Makes}

In the introduction to this chapter we noted that in PNG and Australia the state is largely seen as 'the enemy' in the eyes of customary owners seeking some good to come out of permitting mining or oil and gas extraction from their land. This, in turn, informed peoples' experiences and perception of state absence and/or presence and created space for experience of the 'absent presence' phenomena, where the presence of the state is experienced through its perceived absence. We asked: is there an alternative where the state is not the enemy? Is there a different kind of a state? And what impact would such difference have on the role and experience of the state in resource contexts?

As we have demonstrated above, New Caledonia's 'collegial' government is of a different form where electors vote once and their representatives are filtered by party list into the Congress, and then 11 are chosen to form the territorial government, which will always be from a mix of parties. While parties may differ in their support for broad platforms hammered out over years of consultation, such as the Framework for the Development of Mineral Resources discussed earlier, when voters back them their positions are carried all the way through to the formation of the territorial government so that alternative voices remain intact among the executive. This makes New Caledonia a different kind of state when compared to PNG and Australia. 
There are also similarities between PNG, Australia and New Caledonia, which emerge from the comparative material presented above, and our findings demonstrate the value of the comparative approach adopted here. Most notably, our analysis shows that crisis plays a central role in shaping-or rather, periodically resetting-public and industry policies in all three places. Even when all the tools to control and exercise powers are present in principle, crisis appears to act as a policy brake, forcing perspectives to remain local and focused on particular projects, political movements and communities. What sets New Caledonia-and notably its North Province-apart is that, when things are democratically in step, the policy brake reaches directly from communities into the heart of government. When things are out of step, of course, conflicts jolt those in power and bring them to the table. In PNG and Australia, the first scenario is rare. In many cases, the only recourse that communities have is to go on treating the state as the enemy, experienced through its irrelevant presence or malevolent absence, or a phenomenon described in this volume as 'absent presence'-which is especially evident when the state fails to meet expectations and fulfil its role in resource contexts, when it is present for some but absent for others, and where its presence (and absence) fluctuate over time.

In their work on the resource curse theory, Emma Gilberthorpe and Dinah Rajak (2017) discuss the roles of marginalised or subaltern actors on the one hand, and the elite agencies of actors with power on the other. Their aim is to shift the focus away from revenue management and to make the social and political relations of extraction 'front and centre'. We can agree with this and suggest that it is not the problem of resource rents in the three jurisdictions that exposes them to a resource curse pathology, but the degree to which decisions made at the top fall in line with the interests of citizen stakeholders. In this respect, New Caledonia holds an advance over Australia and PNG in that, as we said above, the state cannot absent itself.

This may be a counter-intuitive proposition to make for a jurisdiction so divided over the politics of territorial sovereignty, and on other matters, and we are certainly not waving away the deep fissure that has existed for so long between loyalists and separatists. What we observe is that exactly the same balance of these political forces as exists in society as a whole is mirrored in the Congress, in the government of New Caledonia, and indeed in the review body, the Comité des signataires. Citizens may not obtain satisfaction that the positions they debate among themselves can 
be resolved easily, but at least they can be sure they are the same ones that are fought out in the Congress, and in the executive government above that. At the same time, as we show here, interpreted in the context of the historical as well as contemporary relationship between New Caledonia and the French government, and with consideration of Kanak struggles for independence, the questions of absence and presence of the state, or indeed its 'absent presence', gains significant traction. So while the distinctive form of the state in New Caledonia means that, in terms of political representation and forms of governance the state cannot absent itself, exploring the role of the state in resource contexts in terms of an interplay between its presence and absence, and how they demonstrate at different levels of discourse and experience, offers new insights and reveals the dynamic and uncertain nature of the state in resource contexts-in PNG and Australia, as well as New Caledonia.

\section{References}

AFG (Australian Federal Government), 2010. Australia's Future Tax System: Overview. Canberra: Department of Treasury.

_ 2016. 'Petroleum Resource Rent Tax Review: Final Report.' Canberra: Department of Treasury.

— 2019. Australia's Critical Minerals Strategy. Canberra: Productivity Commission.

- 2020. Trade and Assistance Review 2018-19. Canberra: Department of Industry, Innovation and Science.

AGA (Applied Geology Associates), 1989. 'Environmental, Socio-economic and Public Health Review of Bougainville Copper Mine, Panguna.' Unpublished report to PNG Department of Minerals and Energy.

Altman, J., 2009. 'Indigenous Communities, Miners and the State in Australia.' In J. Altman and D. Martin (eds), Power, Culture, Economy: Indigenous Australians and Mining. Canberra: ANU E Press (Centre for Aboriginal Economic Policy Research, Research Monograph 30). doi.org/10.22459/ CAEPR30.08.2009

Anon., 2020a. 'Dreams of a Better Future.' Post-Courier, 25 May. 
, 2020b. 'Export de minerai: la province Nord opposée à la dilapidation du patrimoine calédonien' [Mineral Exports: The North Provinces Opposes the Squandering of Territorial Resources]. Les Nouvelles Calédoniennes, 9 July.

Bainton, N.A., 2010. The Lihir Destiny: Cultural Responses to Mining in Melanesia. Canberra: ANU E Press (Asia-Pacific Environment Monograph 5). doi.org/ 10.22459/ld.10.2010

Bainton, N.A., J.R. Owen, S. Kenema and J. Burton, 2020. 'Land, Labour and Capital: Small and Large-Scale Miners in Papua New Guinea.' Resources Policy 68: 101805. doi.org/10.1016/j.resourpol.2020.101805

Bambridge, S., 1979. Australian Minerals and Energy Policy. Canberra: Australian National University Press.

Banks, G.A., 2001. 'Papua New Guinea Baseline Study.' London: International Institute for Environment and Development, Mining Minerals and Sustainable Development Project (Working Paper 180).

Banks, G.A. and C. Ballard (eds), 1997. The Ok Tedi Settlement: Issues, Outcomes and Implications. Canberra: The Australian National University, National Centre for Development Studies (Pacific Policy Paper 27).

Banks, G.A. and M. Namorong, 2018. 'Papua New Guinea’s Disappearing Resource Revenues.' DevPolicy blog, 15 April. Viewed 22 September 2020 at: www. devpolicy.org/papua-new-guineas-disappearing-resource-revenues-20180815/

Bebbington, A., 2014. 'Governing Natural Resources for Inclusive Development.' In S. Hickey, K. Sen and B. Bukenya (eds), The Politics of Inclusive Development: Interrogating the Evidence. Oxford: Oxford University Press. doi.org/10.1093/ acprof:oso/9780198722564.003.0004

Bencivengo, Y., 2014. Nickel : La naissance de l'industrie calédonienne [Nickel: The Birth of the Industry in New Caledonia]. Tours: Presses Universitaires François Rabelais. doi.org/10.4000/books.pufr.12654

Black, P., 2014. 'Green Gold': The Contribution of New Caledonia's Nickel Industry to the 'Age of Steel' 1870-1920. Canberra: The Australian National University (PhD thesis).

Bouard S., C. Levacher, Y. Bencivengo, L. Decottigny, C. Demmer, P.Y. Le Meur, S. Blaise, J Burton, F. Enjuanes and S. Grochain, 2019. 'PME Minières en Nouvelle-Calédonie: Petites et Moyennes Entreprises Minières en NouvelleCalédonie' [Mining SMEs in New Caledonia: Small and Medium Mining Enterprises in New Caledonia]. Nouméa: Institut de Recherche pour le Développement. 
Bouard, S., J.-M. Sourisseau, V. Geronimi, S. Blaise and L. Ro'i (eds), 2016. La Nouvelle-Calédonie face à son destin. Quel bilan à la veille de la consultation sur la pleine souveraineté? [New Caledonia Facing its Destiny: What is the State of Things on the Eve of the Referendum on Independence?] Paris: Éditions Karthala.

Bougainville Copper Limited, 1988. Annual Report 1988. Melbourne: Bougainville Copper Limited.

Braithwaite, J., H. Charlesworth, P. Reddy and L. Dunn, 2010. Reconciliation and Architectures of Commitment: Sequencing Peace in Bougainville. Canberra: ANU E Press. doi.org/10.22459/RAC.09.2010

Brou, B., 1982. 30 Ans d'Histoire de la Nouvelle-Calédonie: 1945/1977 [30 Years in the History of New Caledonia: 1945-77]. Nouméa: Société d'Études Historiques de la Nouvelle-Calédonie.

Burton, J., 1997. 'Terra Nugax and the Discovery Paradigm: How Ok Tedi was Shaped by the Way it was Found and how the Rise of Political Process in the North Fly took the Company by Surprise.' In G.A. Banks and C. Ballard (eds), The Ok Tedi Settlement: Issues, Outcomes and Implications. Canberra: The Australian National University, National Centre for Development Studies (Pacific Policy Paper 27).

Burton, J. and Y. Haihuie, 2017. 'Corruption Risks in Mining Awards: Papua New Guinea Country Report.' Port Moresby: Transparency International Papua New Guinea.

Burton, J. and J. Onguglo, 2017. 'Disconnected Development Worlds: Responsibility towards Local Communities in Papua New Guinea.' In C. Filer and P.-Y. Le Meur (eds), Large-Scale Mines and Local-Level Politics: Between New Caledonia and Papua New Guinea. Canberra: ANU Press (Asia-Pacific Environment Monograph 12). doi.org/10.22459/LMLP.10.2017.09

Chenoweth, N., 2020. 'And the Winners from BHP's Singapore Sling are ...' Australian Financial Review, 3 June.

Childs, J., 2016. 'Geography and Resource Nationalism: A Critical Review and Reframing.' Extractive Industries and Society 3: 539-546. doi.org/10.1016/ j.exis.2016.02.006

CSIRO (Commonwealth Scientific and Industrial Research Organisation), 1996. 'Review of Riverine Impacts.' Unpublished report to Porgera Joint Venture.

DAE (Deloitte Access Economics), 2020. 'Estimates of Royalties and Company Tax Accrued in 2018-19.' Canberra: DAE for Minerals Council of Australia. 
Davis, M., 1993. 'How PNG pulled off the Porgera Coup.' Australian Financial Review, 23 April.

\section{February.}

Demmer, C., 2007. 'Autochtonie, nickel et environnement. Une nouvelle stratégie kanake' [Independence, Nickel and the Environment: A New Strategy for the Kanaks]. Vacarme 39: 43-48. doi.org/10.3917/vaca.039.0043

— 2017. 'L'export du nickel au cœur du débat politique néo-calédonien' [The Export of Nickel at the Heart of Political Debate in New Caledonia]. Mouvements 91: 130-140. doi.org/10.3917/mouv.091.0130

Demmer, C., P.-Y. Le Meur, J.-M. Sourisseau, 2018. 'Quelle stratégie nickel après le référendum d'indépendance?' [What Strategy for Nickel After the Referendum on Independence?]. Le Monde, 30 October.

Filer, C., 1990. 'The Bougainville Rebellion, the Mining Industry and the Process of Social Disintegration in Papua New Guinea.' In R.J. May and M. Spriggs (eds), The Bougainville Crisis. Bathurst (NSW): Crawford House Press.

- 1997. 'The Melanesian Way of Menacing the Mining Industry.' In B. Burt and C. Clerk (eds), Environment and Development in the Pacific Islands. Canberra: The Australian National University, National Centre for Development Studies (Pacific Policy Paper 25).

- 2008. 'Development Forum in Papua New Guinea: Upsides and Downsides.' Journal of Energy \& Natural Resources Law 26: 120-149. doi.org/ 10.1080/02646811.2008.11435180

Filer, C. and B. Imbun, 2009. 'A Short History of Mineral Development Policies in Papua New Guinea, 1972-2002.' In R.J. May (ed.), Policy Making and Implementation: Studies from Papua New Guinea. Canberra: ANU E Press. doi.org/10.22459/PMI.09.2009.06

Filer, C. and P.-Y. Le Meur. 2017. 'Large-Scale Mines and Local-Level Politics.' In C. Filer and P.Y. Le Meur (eds), Large-Scale Mines and Local-Level Politics: Between New Caledonia and Papua New Guinea. Canberra: ANU Press (AsiaPacific Environment Monograph 12). doi.org/10.22459/LMLP.10.2017.01

Garnaut, R. and A. Clunies Ross, 1975. 'Uncertainty, Risk Aversion and the Taxing of Natural Resource Projects.' Economic Journal 85: 272-287. doi.org/ $10.2307 / 2230992$ 
Gilberthorpe, E. and D. Rajak, 2017. 'The Anthropology of Extraction: Critical Perspectives on the Resource Curse.' Journal of Development Studies 53: 186204. doi.org/10.1080/00220388.2016.1160064

Golub, A., 2014. Leviathans at the Gold Mine: Creating Indigenous and Corporate Actors in Papua New Guinea. Durham (NC): Duke University Press.

GPNG (Government of Papua New Guinea), 2009. Papua New Guinea Vision 2050. Port Moresby: National Strategic Plan Taskforce.

, 2015. National Strategy for Responsible Sustainable Development. Port Moresby: Department of National Planning and Monitoring.

2018. An Investigation into the Alleged Improper Borrowing of AU\$1.239 Billion Loan from the Union Bank of Switzerland. Port Moresby: Ombudsman Commission.

Grigg, A., J. Shapiro and L. Murray, 2019. 'Swiss Regulator Probes UBS Australia's \$1.2b PNG Loan.' Australian Financial Review, 15 March.

HCRNC (Haut-Commissariat de la République en Nouvelle-Calédonie), 2019. 'Les résultats du référendum 2018: Résultats définitifs' [Outcome of the 2018 Referendum: Final Figures]. Nouméa: HCRNC.

— 2020. 'Référendum du 4 octobre 2020-Résultats définitifs' [Referendum of 4 October 2020: Final Figures]. Nouméa: HCRNC.

Horowitz, L.S., 2009. 'Environmental Violence and Crises of Legitimacy in New Caledonia.' Political Geography 28: 248-258. doi.org/10.1016/j.polgeo.2009. 07.001

— 2015. 'Culturally Articulated Neoliberalisation: Corporate Social Responsibility and the Capture of Indigenous Legitimacy in New Caledonia.' Transactions of the Institute of British Geographers 40: 88-101.

-, 2016. 'Rhizomic Resistance Meets Arborescence Assemblage: UNESCO World Heritage and the Disempowerment of Indigenous Activism in New Caledonia.' Annals of the American Association of Geographers 106: 167-185. doi.org/10.1080/00045608.2015.1090270

Jackson, R., 1982. Ok Tedi: The Pot of Gold. Port Moresby: University of Papua New Guinea.

Jackson, R. and G.A. Banks, 2002. In Search of the Serpent's Skin: The Story of the Porgera Gold Project. Port Moresby: Placer Niugini. 
Johnson, P., 2012. 'Lode Shedding: A Case Study of the Economic Benefits to the Landowners, the Provincial Government, and the State from the Porgera Gold Mine: Background and Financial Flows from the Mine.' Port Moresby: National Research Institute (Discussion Paper 124).

Kemp, D. and J.R. Owen, 2018. 'The Industrial Ethic, Corporate Refusal and the Demise of the Social Function in Mining.' Sustainable Development 26: 491-500. doi.org/10.1002/sd.1894

Ketan, J. and M. Geita, 2011. An Assessment of the Combined PNG GovernmentMorobe Mining Joint Venture (Hidden Valley) Environmental Audit Consultations and Awareness Program in the Watut and Markham valleys, Morobe Province, Papua New Guinea. Port Moresby: Tanorama Ltd.

Kirsch, S., 2001. 'Lost Worlds, Environmental Disaster, "Culture Loss," and the Law.' Current Anthropology 42: 167-198. doi.org/.10.1086/320006

- 2007. 'Indigenous Movements and the Risks of Counterglobalization: Tracking the Campaign Against Papua New Guinea's Ok Tedi Mine.' American Ethnologist 34: 303-321. doi.org/10.1525/ae.2007.34.2.303

Lalande, C., 2020. 'Vie des usines et après-nickel: des avancées majeures' [Outlook for the Refineries and the Post-Nickel Economy: Significant Developments]. Les Nouvelles Calédoniennes, 5 August.

Le Meur, P.-Y., C. Ballard, G. Banks and J.-M. Sourisseau, 2013. 'Two Islands, Four States: Comparing Resource Governance Regimes in the Southwest Pacific.' Paper presented at the 2nd International Conference on Social Responsibility in Mining, Santiago, 5-8 November.

Le Meur, P.-Y., L.S. Horowitz and T. Mennesson, 2013. "Horizontal" and "Vertical" Diffusion: The Cumulative Influence of Impact and Benefit Agreements (IBAs) on Mining Policy-Production in New Caledonia.' Resources Policy 38: 648-656. doi.org/10.1016/j.resourpol.2013.02.004

Le Meur, P.-Y. and T. Mennesson, 2011. 'Le cadre politico-juridique minier en Nouvelle-Calédonie. Mise en perspective historique' [The Political and Legal Framework for Mining in New Caledonia]. Nouméa: Centre National de Recherche Technologique, Nickel et Son Environnement (Document de Travail 3).

Levacher, C., 2016. De la terre à la mine? Les chemins de l'autochtonie en Nouvelle-Calédonie [From the Earth to the Mine? Indigenous Pathways in New Caledonia]. Paris: École des Hautes Études en Sciences Sociales (PhD thesis). 
2017. 'Contesting the Goro Nickel Mining Project, New Caledonia: Indigenous Rights, Sustainable Development and the Land Issue.' In C. Filer and P.-Y. Le Meur (eds), Large-Scale Mines and Local-Level Politics: Between New Caledonia and Papua New Guinea. Canberra: ANU Press (Asia-Pacific Environment Monograph 12). doi.org/10.22459/lmlp.10.2017.06

Levacher, C. and P.-Y. Le Meur, 2019. 'The Compensation Arenas in South New Caledonia: Minescape Management, Governmentality and Politics.' Paper presented at a workshop on 'The Micropolitics of Mining Capitalism', University of Liège, 11-13 September.

Lund, C., 2006. 'Twilight Institutions: Public Authority and Local Politics in Africa.' Development and Change 37: 685-705. doi.org/10.1111/j.1467-7660. 2006.00497.x

Mainguet, Y., 2019. 'Vale abaisse sérieusement la cote de l'usine du Sud' [Vale Writes Down the Southern Plant]. Les Nouvelles Calédoniennes, 29 November.

_ 2020. 'Kouaoua: que contient le protocole signé?' [Kouaoua: What does the Agreement Say?] Les Nouvelles Calédoniennes, 6 July.

May, R.J. and M. Spriggs (eds), 1990. The Bougainville Crisis. Bathurst (NSW): Crawford House Press.

Merlin, J., 2014. 'L'émergence d'une compétence environnementale autochtone?' [The Emergence of an Indigenous Capacity for Environmental Monitoring]. Terrains and travaux 24: 85-102. doi.org/10.3917/tt.024.0085

Nalu, M., 2013. 'Govt to Debate Mine Takeover.' The National, 18 September.

Newbury, C., 1955. 'La Société "Le Nickel”, de sa fondation à la fin de la deuxième guerre mondiale, 1880-1945.' ['Société Le Nickel': From its Foundation to the end of the Second World War]. Journal de la Société des Océanistes 11: 97-123. doi.org/10.3406/jso.1955.1847

Nicholas, I., 2011. 'Gas Owners Fight over K115mil.' The National, 23 February. 2 February.

OCAA (Oxfam Community Aid Abroad), 2004. 'Mining Ombudsman Case Report: Tolukuma Gold Mine.' Melbourne: OCAA.

Osborne, D., 2014. 'What has happened to Papua New Guinea's Sovereign Wealth Fund?' DevPolicy blog, 28 October. Viewed 22 September 2020 at: devpolicy.org/what-has-happened-to-papua-new-guineas-sovereign-wealthfund-20141028/ 
Owen, W., 2020. 'Australia Officially the World's Largest Exporter of LNG.' LNG Industry blog, 6 January. Viewed 25 September 2020 at: www.Ingindustry. com/liquid-natural-gas/06012020/australia-officially-the-worlds-largestexporter-of-lng/

Pitoiset, A. and C. Wéry, 2008. Mystère Dang [The Mystery of André Dang]. Nouméa: Le Rayon Vert.

PNGEITI (PNG Extractive Industries Transparency Initiative), 2019. 'Papua New Guinea 2018 EITI Report.' Port Moresby: PNGEITI Secretariat.

Rothwell, D., 2018. 'Australia and Timor Leste Settle Maritime Boundary after 45 Years of Bickering.' The Conversation, 7 March.

Swyngedouw, E., 2004. 'Globalisation or "Glocalisation”? Networks, Territories and Rescaling. Cambridge Review of International Affairs 17: 25-48. doi.org/ $10.1080 / 0955757042000203632$

Taylor, A., 2020. 'Australia to Boost Fuel Security and Establish National Oil Reserve.' Media Release from the Minister for Energy and Emissions Reduction, April 22.

Taylor, J. and B. Scambary, 2005. Indigenous People and the Pilbara Mining Boom: A Baseline for Regional Participation. Canberra: ANU E Press (Centre for Aboriginal Economic Policy Research Monograph 25). doi.org/10.22459/ IPPMB.01.2006

TP News, 2020. 'Mining Group Rio Tinto in new \$86 Million Dispute with ATO Over Pricing of Aluminium.' TPcases blog, 9 April. Viewed 25 September 2020 at: tpcases.com/mining-group-rio-tinto-in-new-86-million-dispute-withato-over-pricing-of-aluminium/

UNDP (United Nations Development Programme), 2014. From Wealth to Wellbeing: Translating Resource Revenue into Sustainable Human Development. Port Moresby: UNDP and PNG Department of National Planning and Monitoring (National Human Development Report).

Valle de Souza, S., B.E. Dollery and M.A. Kortt, 2016. 'A Critical Evaluation of Australian Mineral Resources Rent Tax.' International Journal of Public Administration 40: 472-480. doi.org/10.1080/01900692.2015.1136944

Wallace, C., 2019. 'After Years of Vicious Culture Wars, Hope May Yet Triumph over Hate in Australian Politics.' The Conversation, 8 March. Viewed 29 September 2020 at: theconversation.com/after-years-of-vicious-culturewars-hope-may-yet-triumph-over-hate-in-australian-politics-110887 
Wilson, J.D., 2015. 'Understanding Resource Nationalism: Economic Dynamics and Political Institutions.' Contemporary Politics 21:399-416. doi.org/10.1080/ 13569775.2015 .1013293

Yala, C., O. Sanida and A. Make, 2014. 'The Oil Search Loan: Implications for PNG.' DevPolicy blog, 21 Mach. Viewed 22 September 2020 at: devpolicy. org/the-oil-search-loan-implications-for-png-20140321-2/

Zakharia, N., 2020. 'Minerals Industry Digs Deep for Tax Payments.' Australian Mining blog, 11 March. Viewed 25 September 2020 at: www.australianmining. com.au/oil-gas/news-oil-gas/minerals-industry-digs-deep-for-tax-payments/ 
This text is taken from The Absent Presence of the State in LargeScale Resource Extraction Projects, edited by Nicholas Bainton and Emilia E. Skrzypek, published 2021 by ANU Press, The Australian National University, Canberra, Australia.

doi.org/10.22459/AP.2021.10 